\title{
Endocrine-disrupting chemicals in ovarian function: effects on steroidogenesis, metabolism and nuclear receptor signaling
}

\author{
Zelieann R Craig, Wei Wang and Jodi A Flaws \\ Department of Comparative Biosciences, University of Illinois, 2001 S. Lincoln Avenue, Urbana, Illinois 61802, USA \\ Correspondence should be addressed to J A Flaws; Email: jflaws@illinois.edu
}

\begin{abstract}
Endocrine-disrupting chemicals (EDCs) are exogenous agents with the ability to interfere with processes regulated by endogenous hormones. One such process is female reproductive function. The major reproductive organ in the female is the ovary. Disruptions in ovarian processes by EDCs can lead to adverse outcomes such as anovulation, infertility, estrogen deficiency, and premature ovarian failure among others. This review summarizes the effects of EDCs on ovarian function by describing how they interfere with hormone signaling via two mechanisms: altering the availability of ovarian hormones, and altering binding and activity of the hormone at the receptor level. Among the chemicals covered are pesticides (e.g. dichlorodiphenyltrichloroethane and methoxychlor), plasticizers (e.g. bisphenol A and phthalates), dioxins, polychlorinated biphenyls, and polycyclic aromatic hydrocarbons (e.g. benzo[a]pyrene). Reproduction (2011) 142 633-646
\end{abstract}

\section{Introduction}

According to the Environmental Protection Agency (EPA), an endocrine-disrupting chemical (EDC) is an exogenous agent that interferes with synthesis, secretion, transport, metabolism, binding action, or elimination of natural blood-borne hormones that are responsible for homeostasis, reproduction, and developmental processes. Although previously thought to exert their effects only via nuclear receptors, such as those for sex steroids, today we know that EDCs may also act through membrane receptors, neurotransmitter receptors, orphan receptors, and enzymatic pathways involved in the synthesis of hormones. Reviews of existing literature on EDCs have been published previously and summarize basic and clinical research findings related to endocrine disruption in various organs (Diamanti-Kandarakis et al. 2009), including the ovary (Foster et al. 2004). The present review focuses on endocrine disruption in the ovary and is divided into three sections, two of which are major components of the EPA definition of EDC. First, an introductory section provides the reader with background related to the ovary and its physiology and an introduction to the most widely studied ovarian hormone receptors. Secondly, we discuss examples of chemicals that alter the availability of ovarian hormones (synthesis and metabolism). Finally, we discuss the most commonly studied ovarian hormone receptors and chemicals that alter their activation and signaling. A variety of studies and experimental approaches will be discussed while giving particular emphasis to the in vitro studies that have contributed to expanding our understanding of the mechanisms of action of some of the most popular ovarian EDCs.

\section{The ovary}

The cycling ovary contains ovarian follicles at different stages of development and, following ovulation, one or more corpora lutea depending on the species. The process by which the most immature follicles (primordial) develop into preovulatory follicles is termed folliculogenesis (reviewed in Oktem \& Urman (2010)). Primordial follicles exist in a finite number and consist of a single oocyte (egg) surrounded by a single layer of flattened somatic cells known as granulosa cells. During folliculogenesis, granulosa cells become activated, change into a cuboidal shape, and proliferate forming multiple layers around the oocyte. Also, during this process, the oocyte grows, and additional somatic cells known as theca cells are recruited to the follicular structure. Finally, toward the end of folliculogenesis, the follicle obtains a fluid-filled cavity known as the antrum. At this time, the follicle is now referred to as an antral follicle. Antral follicles are the major source of the ovarian steroids and are capable of ovulation following proper stimulation by LH. After ovulation or expulsion of the oocyte from the follicle, the remaining granulosa and theca cells undergo a process of differentiation known as luteinization. During luteinization, the granulosa and theca cells become luteal cells and the former follicular structure is now known as a corpus luteum. A functional 
corpus luteum produces progesterone, the hormone necessary for successful implantation and maintenance of pregnancy. If fertilization does not occur, or a pregnancy is not accomplished, the corpus luteum will undergo a process of cell death known as luteolysis or corpus luteum regression. Disruption of the process of folliculogenesis and corpus luteum formation can lead to adverse reproductive outcomes such as anovulation, infertility, decreased fecundity, estrogen deficiency, and premature ovarian failure.

\section{Ovarian steroidogenesis}

Both major ovarian structures, the antral follicle and the corpus luteum, are steroidogenic glands. Antral follicle steroidogenesis has been described by the two-cell, twogonadotropin theory of ovarian steroidogenesis. Specifically, this theory describes how granulosa and theca cells work together to make the ovarian steroids (Falck (1959); and others reviewed in Richards (1980); Fig. 1). Theca cells possess receptors for $\mathrm{LH}$, which is released from the anterior pituitary (Channing \& Kammerman (1974); and others reviewed in Richards (1980)). Upon binding to its receptor, LH signals theca cells to increase transcription of genes encoding the enzymes necessary for conversion of cholesterol to androgens (androstenedione and testosterone). On the other hand, granulosa cells possess receptors for $\mathrm{FSH}$, which is also released from the anterior pituitary (Carson et al. (1979); and others reviewed in Richards (1980)). Upon binding to its receptor, FSH signals granulosa cells to increase transcription of genes encoding the enzymes necessary for conversion of theca-derived androgens into estrogens (17 $\beta$-estradiol $\left(E_{2}\right)$ and estrone). In the theca cell, cholesterol is either internalized by lipoprotein receptors or synthesized de novo. Once in the cytoplasm, cholesterol is transported into the mitochondria by STAR (Strauss et al. 1999, Christenson \& Strauss 2000, Stocco 2001). In the mitochondria, cholesterol is converted to pregnenolone by cytochrome $\mathrm{P} 450$ cholesterol side-chain cleavage (CYP450scc; CYP11A1; Miller 1988, Hanukoglu 1992). Pregnenolone diffuses from the mitochondria into the smooth endoplasmic reticulum where it can be converted to progesterone by $3 \beta$ hydroxysteroid dehydrogenase (HSD3B; Penning 1997) or to DHEA by $17 \alpha$-hydroxylase-17,20-desmolase (CYP45017 $\alpha$; CYP17A1). Both HSD3B and CYP17A1 will catalyze the conversion of DHEA and progesterone to androstenedione (Hanukoglu 1992) respectively. Androstenedione can either be converted to testosterone by $17 \beta$-hydroxysteroid dehydrogenase (HSD17B) within the theca cell or diffuse into the granulosa cell. In the granulosa cell, aromatase (CYP450arom; CYP19A1) can convert androstenedione to estrone and testosterone to

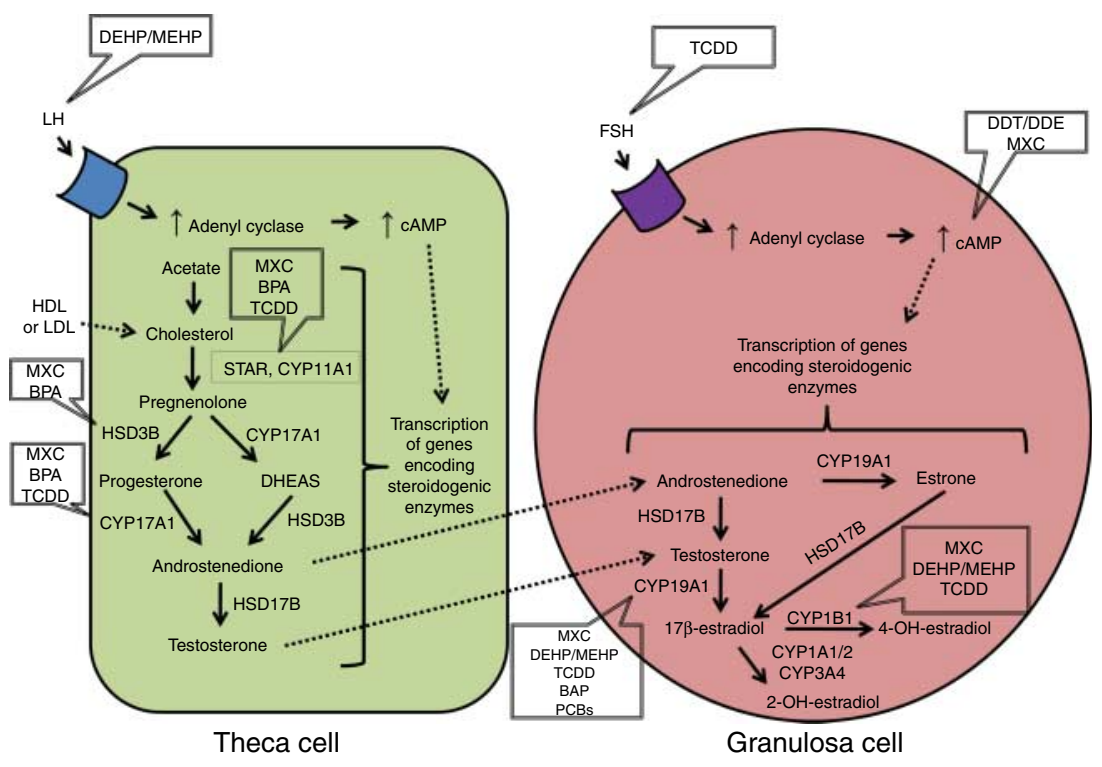

Figure 1 Ovarian steroidogenesis. Ovarian steroidogenesis requires the cooperative interactions of the theca and granulosa cells within the follicle. Theca cells respond to LH signaling by increasing the expression of enzymes necessary for the conversion of cholesterol to androgens (androstenedione and testosterone). Granulosa cells respond to FSH signaling by increasing the expression of enzymes necessary for the conversion of theca-derived androgens into estrogens (17ß-estradiol and estrone). Finally, the major estrogen, $17 \beta$-estradiol can be further metabolized into hydroxylated metabolites and, thus, becomes inactive. Several chemicals have been shown to target various steps within this pathway and are shown in callout boxes. HDL, high-density lipoprotein; LDL, low-density lipoprotein; CYP11A1, cytochrome P450 11A1 or cholesterol side-chain cleavage; HSD3B, 3ß-hydroxysteroid dehydrogenase; CYP17A1, cytochrome P450 17A1 or $17 \alpha$-hydroxylase, 17,20-desmolase; HSD17B, 17ß-hydroxysteroid dehydrogenase; CYP19A1, cytochrome P450 19A1 or aromatase; CYP1B1, cytochrome P450 1B1; CYP1A1/2, cytochrome P450 A1 and A2; CYP3A4, cytochrome P450 3A4; MXC, methoxychlor; BPA, bisphenol A; TCDD, 2,3,7,8-tetrachlorodibenzo- $p$-dioxin; DDT, dichlorodiphenyltrichloroethane; DDE, 1,1-dichloro-2,2-bis(4-chlorophenyl)ethylene; DEHP, di-(2-ethylhexyl) phthalate; MEHP, mono-2ethylhexyl phthalate; BAP, benzo[a]pyrene; PCBs, polychlorinated biphenyls. 
$E_{2}$ (Hanukoglu 1992). Furthermore, granulosa cells can convert estrone to $E_{2}$ through the action of HSD17B (Penning 1997). $E_{2}$ is the most potent form of estrogen in female reproduction. However, following its synthesis, $E_{2}$ can be further metabolized into 2-hydroxyestradiol by CYP1A1/2 and CYP3A4, or to 4-hydroxyestradiol by CYP1B1 (Hayes et al. 1996, Tsuchiya et al. 2005). These modifications lead to inactivation of $E_{2}$ and further modifications are thought to lead to cell damage (Tsuchiya et al. 2005).

Several chemicals have the ability to alter the synthesis and metabolism of ovarian sex steroid hormones by altering the expression and catalytic activity of these enzymes. Therefore, endocrine disruption occurs when the hormone is no longer available to bind its receptor and fails to elicit its physiological function (Tables 1 and 2).

\section{Ovarian hormone receptors}

The ovarian hormone receptors include those for the sex steroid hormones estrogen, progestins, and androgens (reviewed in Drummond et al. (2002) and Brosens (2004)), as well as orphan receptors like the aryl hydrocarbon receptor (AHR; reviewed in Pocar et al. (2005)) and the gonadotropin receptors, which bind LH and FSH. The sex steroid hormone receptors and the AHR are ligand-dependent transcription factors that bind DNA and control expression of specific genes. On the other hand, LH and FSH receptors are G protein-coupled receptors that modulate cell function by activating second messenger signaling pathways upon binding to their peptide hormone ligands (Magoffin \& Erickson 1982, Wang et al. 1982). A growing number of environmental contaminants, which are considered endocrine disruptors, can cause ovarian toxicity. In the ovary, most studies have focused on the effects of EDCs on estrogen receptors (ESRs), the $A H R$ and the androgen receptor (AR).

\section{Chemicals that alter the availability of ovarian hormones \\ Pesticides: dichlorodiphenyltrichloroethane and methoxychlor}

Dichlorodiphenyltrichloroethane (DDT) is a broadspectrum insecticide widely used in the 1940s, but presently banned in many countries. In mammals, DDT is mainly metabolized by dechlorination and subsequent dehydrochlorination to 1,1-dichloro-2,2-bis(4-chlorophenyl)ethylene, referred to as DDE (Gold \& Brunk 1982). The effects of DDT and DDE on the female reproductive system have been widely studied and have been reviewed elsewhere (Tiemann 2008). Early evidence supporting DDT and DDE as endocrine disruptors came from studies reporting altered sex steroid hormone concentrations in alligators hatched from eggs obtained from contaminated lakes (Guillette et al. 1995, 1996). Also, evidence supporting exposure to DDT and DDE as a public concern has risen from studies reporting the presence of these chemicals in serum (range: $1.08-1.68 \mathrm{ng} / \mathrm{ml})$ and follicular fluid $(0.01-1.11 \mathrm{ng} / \mathrm{ml})$ of women (Jarrell et al. 1993, De Felip et al. 2004, Al-Saleh et al. 2009, Meeker et al. 2009), farm animals $(0.16-1.50 \mathrm{ng} / \mathrm{ml}$; Kamarianos et al. 2003) and the fact that they can accumulate in the egg-forming tissues and egg yolk of laying hens (Furusawa 2002). Studies using porcine granulosa cells have demonstrated that DDE alters progesterone synthesis. Specifically, it has been shown that at low concentrations $(10 \mathrm{ng} / \mathrm{ml}), \mathrm{DDE}$ is able to increase progesterone synthesis by porcine granulosa cells (Crellin et al. 1999). Interestingly, higher concentrations of DDE $(0.3-320 \mu \mathrm{g} / \mathrm{ml})$ were shown to block progesterone synthesis in stable and primary cultures of porcine granulosa cells (Chedrese \& Feyles 2001, Crellin et al. 2001). In fact, different effects on steroidogenesis have been reported for isomers of DDT isomers $\left(p, p^{\prime}-\right.$ and $o, p^{\prime}$-DDT) and isomers of its metabolite DDE $\left(p, p^{\prime}\right.$ - and $o, p^{\prime}$-DDE) in porcine follicular cells. Specifically, $p, p^{\prime}$-DDT $(0.4-4 \mu \mathrm{g} / \mathrm{ml})$ was shown to decrease $\mathrm{E}_{2}$ production, while $o, p^{\prime}$-DDT and the DDE isomers at doses ranging from 0.004 to $4 \mu \mathrm{g} / \mathrm{ml}$ increased it. Also, progesterone secretion was decreased by addition of DDT isomers and $p, p^{\prime}$-DDE $(4 \mu \mathrm{g} / \mathrm{ml})$, but not by o, $p^{\prime}$-DDE (Wójtowicz et al. 2007). As far as the mechanism(s) by which DDE alters steroidogenesis, it has been observed that high doses of DDE $(\sim 3-32 \mu \mathrm{g} / \mathrm{ml})$ lead to decreased cAMP synthesis (Chedrese \& Feyles 2001) and decreased expression of Cyp11a1 (Crellin et al. 2001) in porcine granulosa cells. Therefore, it is thought that DDE decreases progesterone synthesis in granulosa cells by impairing generation of CAMP, which leads to reduced transcription of Cyp11a1 mRNA. In turn, decreased levels of Cyp11a1 mRNA, which encodes the main rate-limiting enzyme in ovarian steroidogenesis, are responsible for decreased synthesis of ovarian sex steroids such as progesterone and $E_{2}$. However, the mechanism by which different doses of DDT and/or isomers cause opposite effects (e.g. increased/decreased progesterone) is not well understood. Perhaps this can be attributed to differences in affinity for receptors and/or enzymes due to different chemical structures, doses administered and length of exposure. Some studies also suggest that aromatase activity can also be a target of DDT because treatment with DDT and/or DDE $(4 \mu \mathrm{g} / \mathrm{ml})$ results in increased aromatase activity in porcine follicular cells (Wójtowicz et al. 2007) and human granulosa cells $(100 \mathrm{ng} / \mathrm{ml}$; Younglai et al. 2004a). Furthermore, another study demonstrated that DDE $(100 \mathrm{ng} / \mathrm{ml})$ can stimulate calcium $\left(\mathrm{Ca}^{2+}\right)$ mobilization in human granulosa-lutein cells (Younglai et al. 2004b). Therefore, DDT may not only interfere with gonadotropin receptor signaling second messengers such as CAMP, but also may directly 
Table 1 Selected chemicals that alter availability of ovarian hormones.

\begin{tabular}{|c|c|c|c|}
\hline Chemical & Species & Effect & Reference(s) \\
\hline \multirow[t]{7}{*}{ DDT/DDE } & Alligators & $\downarrow$ Sex steroid levels & Guillette et al. $(1995,1996)$ \\
\hline & \multirow[t]{3}{*}{ Porcine granulosa cells } & $\uparrow$ Progesterone synthesis; low doses & Crellin et al. (1999) \\
\hline & & $\downarrow$ Progesterone synthesis; high doses & $\begin{array}{l}\text { Chedrese \& Feyles (2001) } \\
\text { and Crellin et al. (2001) }\end{array}$ \\
\hline & & $\downarrow$ Cyp11a1 mRNA & $\begin{array}{l}\text { Chedrese \& Feyles (2001) } \\
\text { and Crellin et al. (2001) }\end{array}$ \\
\hline & \multirow[t]{2}{*}{ Porcine theca/granulosa cells } & $\uparrow \mathrm{E}_{2}$ and testosterone production & Wójtowicz et al. (2007) \\
\hline & & $\uparrow$ Aromatase activity & Wójtowicz et al. (2007) \\
\hline & Human granulosa cells & $\uparrow$ Aromatase activity & Younglai et al. (2004a) \\
\hline \multirow[t]{6}{*}{ MXC } & Pregnant rats & $\begin{array}{l}\downarrow \text { Serum progesterone levels; } \downarrow \text { ex vivo } \mathrm{E}_{2} \text { and } \\
\text { testosterone production }\end{array}$ & Cummings \& Laskey (1993) \\
\hline & Xenopus ovaries & $\downarrow$ Progesterone synthesis & Pickford \& Morris (2003) \\
\hline & \multirow[t]{2}{*}{ Porcine granulosa cells } & $\uparrow$ Progesterone synthesis & Chedrese \& Feyles (2001) \\
\hline & & $\uparrow$ Cyp11a1 mRNA & Crellin et al. (2001) \\
\hline & \multirow{2}{*}{ Mouse antral follicles } & $\uparrow$ Cyp1b1 mRNA & Basavarajappa et al. (2011) \\
\hline & & $\begin{array}{l}\downarrow \text { Star, Cyp11a1, Hsd3b1, Cyp17a1, and Cyp19a1 } \\
\text { mRNAs }\end{array}$ & Basavarajappa et al. (2011) \\
\hline \multirow[t]{2}{*}{ Mono-OH MXC } & \multirow[t]{2}{*}{ Mouse antral follicles } & $\downarrow$ Progesterone, androstenedione, testosterone, $\mathrm{E}_{2}$ & Craig et al. (2010) \\
\hline & & $\downarrow$ Cyp11a1, Cyp17a1, Cyp19a1, and mRNA & Craig et al. (2010) \\
\hline \multirow[t]{6}{*}{ HPTE } & \multirow[t]{5}{*}{ Rat granulosa cells } & $\downarrow \mathrm{FSH}$-stimulated progesterone and $\mathrm{E}_{2}$ synthesis & Zachow \& Uzumcu (2006) \\
\hline & & $\downarrow$ FSH-induced Cyp11a1 and Cyp19a1 mRNAs & Zachow \& Uzumcu (2006) \\
\hline & & $\downarrow$ Inha, Inhba, Kitl, and Igf1 mRNAs & Harvey et al. (2009) \\
\hline & & $\leftrightarrow$ Cyp11a1 mRNA, protein, and catalytic activity & Akgul et al. (2008) \\
\hline & & $\downarrow$ Cyp11a1, Hsd3b1, and Cyp19a1 mRNAs & Harvey et al. (2009) \\
\hline & Rat theca cells & $\begin{array}{l}\downarrow \text { CYP11A1 catalytic activity; } \leftrightarrow \text { Cyp11a1 } \\
\text { mRNA and protein }\end{array}$ & Akgul et al. (2008) \\
\hline \multirow[t]{15}{*}{ BPA } & \multirow[t]{2}{*}{ Mouse antral follicles } & $\begin{array}{l}\downarrow \text { Progesterone, DHEA, androstenedione, } \\
\text { testosterone, estrone, and } \mathrm{E}_{2}\end{array}$ & Peretz et al. (2011) \\
\hline & & $\downarrow$ Star, Hsd3b1, and Cyp17a1 mRNAs & Peretz et al. (2011) \\
\hline & \multirow{2}{*}{ Rat theca-interstitial cells } & $\uparrow$ Testosterone synthesis & Zhou et al. (2008) \\
\hline & & $\uparrow$ Star, Cyp11a1, and Cyp17a1 mRNAs & Zhou et al. (2008) \\
\hline & \multirow[t]{2}{*}{ Rat granulosa cells } & $\uparrow$ Progesterone production & Zhou et al. (2008) \\
\hline & & $\uparrow$ Cyp11a1 mRNA & Zhou et al. (2008) \\
\hline & \multirow[t]{5}{*}{ Porcine granulosa cells } & $\downarrow$ Progesterone production & $\begin{array}{l}\text { Mlynarcíková et al. (2005) } \\
\text { and Grasselli et al. (2010) }\end{array}$ \\
\hline & & $\uparrow E_{2}$ production; low doses & Grasselli et al. (2010) \\
\hline & & $\downarrow \mathrm{E}_{2}$ production; high doses & Grasselli et al. (2010) \\
\hline & & $\uparrow$ Progesterone levels; dependent on dose & Mlynarcíková et al. (2005) \\
\hline & & $\downarrow \mathrm{E}_{2}$ production; dependent on dose & Mlynarcíková et al. (2005) \\
\hline & Human granulosa cells & $\downarrow$ Cyp19a1 mRNA & Kwintkiewicz et al. (2010) \\
\hline & $\begin{array}{l}\text { Human granulosa-like tumor } \\
\text { cells }\end{array}$ & $\downarrow$ Cyp19a1 mRNA & Kwintkiewicz et al. (2010) \\
\hline & Caiman & $\uparrow$ Serum $E_{2} ; \downarrow$ serum testosterone & Stoker et al. (2008) \\
\hline & Fish & $\downarrow$ Cyp19a1 mRNA & Wang et al. (2010) \\
\hline \multirow{12}{*}{ DEHP/MEHP } & \multirow{3}{*}{ Rats } & $\downarrow \mathrm{E}_{2}$ levels & Xu et al. (2010) \\
\hline & & $\downarrow$ Cyp19a1 mRNA and protein & Ma et al. (2006) \\
\hline & & $\uparrow$ Serum $\mathrm{LH} ; \uparrow$ serum $\mathrm{E}_{2}$ & Ma et al. (2006) \\
\hline & \multirow{2}{*}{ Mouse antral follicles } & $\downarrow E_{2}$ production & Gupta et al. (2010) \\
\hline & & $\downarrow$ Cyp19a1 mRNA; prevented with $\mathrm{E}_{2}$ co-treatment & Gupta et al. (2010) \\
\hline & \multirow{2}{*}{ Mouse preantral follicles } & $\uparrow$ Conversion of $\mathrm{E}_{2}$ to estrone & Lenie \& Smitz (2009) \\
\hline & & Precocious increase in progesterone synthesis & Lenie \& Smitz (2009) \\
\hline & \multirow[t]{2}{*}{ Human granulosa-lutein cells } & $\downarrow E_{2}$ synthesis & Reinsberg et al. (2009) \\
\hline & & $\downarrow$ Cyp19a1 mRNA and activity & Reinsberg et al. (2009) \\
\hline & Rat granulosa cells & $\downarrow$ Serum progesterone levels & Svechnikova et al. (2007) \\
\hline & & $\downarrow$ Cyp19a1 mRNA and protein & Lovekamp \& Davis (2001) \\
\hline & & $\uparrow$ Hsd $17 b 4$ and Cyp $1 b 1$ mRNAs & Lovekamp-Swan et al. (2003) \\
\hline TCDD & Rat; in utero & $\downarrow$ Star and Cyp17a1 mRNAs in ovaries & Takeda et al. (2009) \\
\hline & Rat; in utero+lactational & $\uparrow$ Plasma progesterone & Pesonen et al. (2006) \\
\hline & & $\downarrow$ Plasma $E_{2}$ in dams and pups; $\uparrow$ plasma FSH in pups & Myllymäki et al. (2005b) \\
\hline & & $\downarrow$ Star and Cyp19a 1 mRNAs in pup ovaries & Myllymäki et al. (2005b) \\
\hline & Rat; whole ovary microarray & $\uparrow$ Cyp1b1, $\downarrow$ Cyp $17 a 1$, and $\downarrow$ Gdf9 & Valdez et al. (2009) \\
\hline
\end{tabular}

DDT, dichlorodiphenyltrichloroethane; DDE, 1,1-dichloro-2,2-bis(4-chlorophenyl)ethylene; $\mathrm{E}_{2}$, 17ß-estradiol; MXC, methoxychlor; Mono-OH MXC, mono-hydroxy methoxychlor; HPTE, bis-hydroxy methoxychlor; BPA, bisphenol A; DEHP, di-(2-ethylhexyl) phthalate; MEHP, mono(2-ethylhexyl)phthalate; TCDD, 2,3,7,8-tetrachlorodibenzo-p-dioxin. 
alter enzymatic activity, and modulate $\mathrm{Ca}^{2+}$-dependent pathways. DDT and DDE ( 108 and $98 \mathrm{mg} / \mathrm{kg}$, respectively) have also been shown to increase expression and activity of male rat hepatic cytochrome P450 enzymes such as those in the CYP2 and CYP3 families (Nims et al. 1998). Interestingly, enzymes within the CYP3A sub-family of metabolic enzymes are involved in the metabolism of estrogens in humans (reviewed in Tsuchiya et al. (2005)). Therefore, although no studies have described this phenomenon in females or in ovarian cells, it is important to consider that perhaps DDT may affect hepatic metabolism and increase breakdown of ovarian estrogens. Thus, it is possible that DDT causes endocrine disruption by altering both synthesis and metabolic breakdown of the ovarian steroids.

Methoxychlor (MXC) is an organochlorine pesticide introduced as a less persistent alternative to DDT. Unfortunately, many studies have demonstrated that MXC is also an endocrine disruptor and its effects on female reproduction have been reviewed previously (Tiemann 2008). Evidence for the ability of MXC to alter levels of ovarian hormones has been provided by various groups. Experiments by Cummings \& Laskey (1993) showed that MXC (250-500 mg/kg) reduced serum progesterone levels, impaired implantation and decreased ex vivo production of $E_{2}$ and testosterone in rats. Studies in amphibians have shown that MXC (0.5$25 \mathrm{ng} / \mathrm{ml}$ ) inhibits progesterone synthesis and interferes with progesterone-induced oocyte maturation (Pickford \& Morris 1999, 2003). In cultured porcine granulosa cells, MXC $(0.1-3.5 \mathrm{ng} / \mathrm{ml})$ reduced basal and FSH- and cholera toxin-stimulated progesterone production (Chedrese \& Feyles 2001, Crellin et al. 2001), and increased levels of Cyp11a1 transcript without altering levels of cAMP (Crellin et al. 2001). Therefore, it has been proposed that MXC may affect sex steroid levels by blocking a step in the steroid synthesis pathway that is downstream of generation of CAMP, but upstream of conversion of cholesterol to pregnenolone (Crellin et al. 2001). The fact that MXC has also been shown to increase intracellular $\mathrm{Ca}^{2+}$ concentrations at low doses $(\sim 0.01-0.5 \mu \mathrm{g} / \mathrm{ml}$; Wu et al. 2006), suggests that MXC may interact with membrane receptors and parallel pathways that modulate ovarian steroidogenesis. In mouse antral follicles, MXC $(1-100 \mu \mathrm{g} / \mathrm{ml})$ was shown to decrease expression of mRNAs encoding the main steroidogenic enzymes with subsequent decreases in the main sex steroids (Basavarajappa et al. 2011). Studies in rodents have determined that upon entering the body, MXC is absorbed and sequentially demethylated by hepatic CYP450 enzymes to form a mono-hydroxylated metabolite commonly known as mono-OH and a bishydroxylated metabolite known as HPTE (Imai \& Coulston 1968, Kapoor et al. 1970). It has been proposed that effects of MXC are due to these metabolites. In fact, several studies have shown that these metabolites disrupt ovarian steroidogenesis in vitro. For example, mono-OH $(10 \mu \mathrm{g} / \mathrm{ml})$ decreases synthesis of progesterone, androstenedione, testosterone, and $E_{2}$ in isolated mouse antral follicles (Craig et al. 2010). In that study, decreased steroidogenesis was accompanied by decreased expression of Cyp11a1, Cyp17a1, and Cyp19a1. HPTE $(1-10 \mu \mathrm{M})$ has been shown to reduce FSH-stimulated

Table 2 Chemicals that alter binding and activity of ovarian receptors.

\begin{tabular}{|c|c|c|c|c|}
\hline Receptor & Chemical & Species & Effect & Reference(s) \\
\hline \multirow[t]{9}{*}{ ESR } & \multirow[t]{2}{*}{ DES } & \multirow[t]{2}{*}{ Mouse (neonatal) } & Delayed folliculogenesis (ESR1) & Kim et al. (2009a, 2009b) \\
\hline & & & Polyovular follicles (ESR2) & Kirigaya et al. (2009) \\
\hline & \multirow[t]{4}{*}{ Genistein } & \multirow[t]{4}{*}{ Mouse (neonatal) } & $\downarrow$ Fertility & \multirow{4}{*}{$\begin{array}{l}\text { Jefferson et al. (2002, 2009) } \\
\quad \text { and Cimafranca et al. (2010) }\end{array}$} \\
\hline & & & Polyovular follicles (ESR2) & \\
\hline & & & Altered estrous cycles & \\
\hline & & & Delayed parturition & \\
\hline & MXC & Rat (prenatal and neonatal) & Hypermethylation on ESR2 & Zama \& Uzumcu (2009) \\
\hline & \multirow[t]{2}{*}{ BPA } & Mouse (prenatal) & Disrupting early oogenesis (ESR2) & Susiarjo et al. (2007) \\
\hline & & Mouse (prenatal) & $\downarrow$ Ovulation & Maffini et al. (2006) \\
\hline \multirow[t]{5}{*}{ AHR } & \multirow[t]{3}{*}{ TCDD } & Rat & $\begin{array}{l}\text { Premature reproductive senescence } \\
\downarrow E_{2} \text { levels }\end{array}$ & Shi et al. (2007) \\
\hline & & Porcine & $\uparrow$ The expression of AHR in granulosa cells & Wojtowicz et al. (2005) \\
\hline & & Rat & $\downarrow$ Ovulation by $\downarrow$ the expression of PTGS2 & Mizuyachi et al. (2002) \\
\hline & \multirow[t]{2}{*}{$\mathrm{PAH}$} & Rat (prenatal) & $\downarrow$ Ovarian reserve of female offspring & Jurisicova et al. (2007) \\
\hline & & Mouse & $\begin{array}{l}\uparrow \text { The expression of pro-apoptotic genes } \\
\uparrow \text { Germ cell depletion }\end{array}$ & Pru et al. (2009) \\
\hline $\mathrm{AR}$ & $\mathrm{CNP}$ & In vitro (hamster ovary cell) & Binds to $A R$ as antagonist in ovary & Kojima et al. (2003) \\
\hline PGR & HPTE & Rat & $\downarrow$ PGR expression & Harvey et al. (2009) \\
\hline \multirow[t]{2}{*}{ LHR } & HPTE & Rat & $\downarrow$ LHR expression & Harvey et al. (2009) \\
\hline & TCDD & Rat & $\downarrow$ Expression and mRNA stability of LHR & Minegishi et al. (2003) \\
\hline
\end{tabular}

ESR, estrogen receptor; DES, diethylstilbestrol; ESR1, estrogen receptor $\alpha$; ESR2, estrogen receptor $\beta ;$ MXC, methoxychlor; BPA, bisphenol A; AHR, aryl hydrocarbon receptor; TCDD, 2,3,7,8-tetrachlorodibenzo-p-dioxin; $E_{2}, 17 \beta$-estradiol; PTGS2, prostaglandin-endoperoxide synthase 2 (also known as cyclooxygenase-2 (COX-2)); $\mathrm{PAH}$, polycyclic aromatic hydrocarbon; AR, androgen receptor; CNP, chlornitrofen; PGR, progesterone receptor; HPTE, bis-hydroxy methoxychlor; LHR, LH receptor. 
synthesis of progesterone and $\mathrm{E}_{2}$ in cultured rat granulosa cells (Zachow \& Uzumcu 2006). In that same study, HPTE decreased FSH-induced expression of Cyp11a1 and Cyp19a1. In a similar study, Harvey et al. (2009) reported that HPTE $(5-10 \mu \mathrm{M})$ decreased expression of Cyp11a1, Hsd3b1, and Cyp19a1 in rat granulosa cells in vitro. Furthermore, HPTE (50-100 nM) has been shown to directly inhibit the catalytic activity of CYP11A1 in cultured theca-interstitial cells obtained from immature rats primed with pregnant mare serum gonadotropin (Akgul et al. 2008). However, no changes were detected in granulosa cells and no changes in Cyp11a1 mRNA or protein were detected in thecainterstitial cells (Akgul et al. 2008). Interestingly, a microarray experiment using cultured rat granulosa cells (Harvey et al. 2009) revealed downregulation by HPTE $(10 \mu \mathrm{M})$ of Inhba and Inha mRNAs, which encode subunits of the peptide hormone inhibin. HPTE treatment also downregulated the mRNA expression of ovarian paracrine factors such as kit ligand and insulin-like growth factor 1 . This observation suggests HPTE may also cause paracrine disruption in the ovary. Lastly, evidence exists that MXC is capable of inducing metabolic enzymes involved in the catabolism of $E_{2}$. Specifically, MXC $(200 \mathrm{mg} / \mathrm{kg})$ has been reported to induce expression of rat hepatic Cyp3a1 mRNA (Li \& Kupfer 1998). Furthermore, MXC $(100 \mu \mathrm{g} / \mathrm{ml})$ induces expression of Cyp1b1 mRNA in isolated mouse antral follicles to levels comparable to those stimulated by TCDD, a classical inducer of Cyp1b1 transcription (Basavarajappa et al. 2011). Thus, MXC may not only decrease synthesis of sex steroids, but also increase their catabolism by modulating the expression of the enzymes responsible for these processes.

\section{Plasticizers: bisphenol $A$ and phthalates}

Bisphenol A (BPA) is a plasticizer found in reusable plastic containers, food and beverage can liners, baby bottles and dental sealants among others. BPA exposure has become an important health concern based on its ability to 'leach' from these products and enter the materials contained within them. Human exposure has been confirmed in various tissues including ovarian follicular fluid, and various exposures have been linked to reproductive effects in animal models (reviewed in Hengstler et al. (2011)). Recent studies have been aimed at understanding the effects of BPA on ovarian steroidogenesis in various experimental systems. In mice, BPA (44-440 $\mu \mathrm{M}, 96 \mathrm{~h})$ inhibits growth of antral follicles in vitro and reduces production of progesterone, DHEA, androstenedione, estrone, testosterone, and $E_{2}$. Furthermore, BPA-induced inhibition of steroidogenesis is accompanied by decreased expression of Star, Hsd3b1, and Cyp17a1 transcripts (Peretz et al. 2011). Another study evaluating the effects of BPA on cultured rat theca-interstitial and granulosa cells showed dose- dependent alterations in sex steroid levels and mRNA for steroidogenic enzymes. Specifically, BPA (0.1$100 \mu \mathrm{M}, 48 \mathrm{~h}$ ) increased testosterone synthesis as well as expression of Cyp17a1, Cyp11a1, and Star mRNAs in theca-interstitial cells. In granulosa cells, BPA (0.1$10 \mu \mathrm{M}, 48 \mathrm{~h}$ ) increased progesterone and Cyp11a1 levels, but decreased $E_{2}$ and Cyp19a1 levels when given at concentrations among 1,10 , and $100 \mu \mathrm{M}$ (Zhou et al. 2008). In cultured porcine granulosa cells, all doses of BPA $(0.1-10 \mu \mathrm{M})$ decreased progesterone production, while a low dose of $0.1 \mu \mathrm{M}$ increased $E_{2}$ levels and high doses ranging from 1 to $100 \mu \mathrm{M}$ BPA decreased $E_{2}$ production (Grasselli et al. 2010). Another study with porcine granulosa cells showed that, depending on the dose given, BPA increased basal $(1 \mu \mathrm{M})$ and $\mathrm{FSH}-$ induced $(10 \mu \mathrm{M})$ progesterone production, while it inhibited $(1-100 \mu \mathrm{M}) \mathrm{FSH}$-induced $\mathrm{E}_{2}$ production (Mlynarcíková et al. 2005). Furthermore, BPA (100 $\mu \mathrm{M})$ decreased progesterone production, decreased expansion of cumulus cells and inhibited oocyte maturation in porcine oocyte-cumulus complexes (Mlynarcíková et al. 2009). BPA treatment $(40-100 \mu \mathrm{M})$ decreased aromatase mRNA and protein, and reduced $E_{2}$ production by primary human granulosa cells and a human ovarian granulosa-like tumor cell line (Kwintkiewicz et al. 2010). Neonatal female caiman exposed in ovum to BPA at 1.4 and $140 \mathrm{ppm}$ had increased $E_{2}$ serum levels, while $1.4 \mathrm{ppm}$ BPA resulted in decreased testosterone levels compared with vehicle-treated controls (Stoker et al. 2008). Lastly, expression of ovarian aromatase (Cyp19a1) was downregulated in rare minnow juveniles treated with BPA (0.1-10 nM; Wang et al. 2010). Although various lines of evidence show that BPA alters ovarian steroidogenesis by decreasing expression of key steroidogenic enzymes, the mechanisms by which these alterations occur remains to be determined. Furthermore, the mechanisms underlying the ability of BPA to produce opposite effects on steroid hormone levels and steroidogenic enzyme expression may be due to differences in experimental approaches such as dose given, species and cell type used, and on the length of exposure.

Phthalates are synthetic chemicals used in polyvinyl chloride plastics, beauty and infant products, medical devices, and the enteric coating of some medications. Several groups have documented the ability of phthalates to cause female reproductive toxicity and the subject has been reviewed previously (Lovekamp-Swan \& Davis 2003). In vivo studies in rats showed that di-(2-ethylhexyl) phthalate (DEHP; 300 and $600 \mathrm{mg} / \mathrm{kg}$ ) significantly decreased levels of $E_{2}$, and aromatase mRNA and protein (Xu et al. 2010). In mice, DEHP $(1-100 \mu \mathrm{g} / \mathrm{ml})$ and its metabolite mono-(2-ethylhexyl) phthalate (MEHP; $0.1-10 \mu \mathrm{g} / \mathrm{ml}$ ) inhibit antral follicle growth, reduce in vitro $\mathrm{E}_{2}$ production, and decrease Cyp19a1 expression. Furthermore, DEHP- and MEHP-induced inhibition of follicle growth and 
downregulation of Cyp19a1 mRNA levels were prevented with $E_{2}$ co-treatment (1-10 nM; Gupta et al. 2010). In isolated mouse small preantral follicles, MEHP treatment $(10-200 \mu \mathrm{M})$ resulted in increased inactivation of $E_{2}$ to estrone and a precocious increase in progesterone synthesis (Lenie \& Smitz 2009). In human granulosa-lutein cells, MEHP $(0.6-500 \mu \mathrm{mol} / \mathrm{l})$ suppressed basal and $\mathrm{FSH}-$, hCG-, and 8Br-cAMP-stimulated $E_{2}$ production, and decreased aromatase mRNA and activity (Reinsberg et al. 2009). In porcine oocytecumulus complexes, DEHP increased progesterone production when given at $1 \mu \mathrm{M}$ (Gunnarsson et al. 2008). However, MEHP was found to increase progesterone without altering CAMP levels produced by the granulosa tumor cell line KK-1 (Gunnarsson et al. 2008). A study in rats described the ability of DEHP $(500 \mathrm{mg} / \mathrm{kg})$ to alter ovarian steroidogenesis and production of the gonadotropins by gonadotropes. Specifically, ex vivo production of $\mathrm{LH}$ was increased in gonadotropes obtained from DEHP-treated immature rats while serum progesterone levels were decreased (Svechnikova et al. 2007). However, a different study showed that inhaled DEHP (5 and $25 \mathrm{mg} / \mathrm{m}^{3}$ ) increased levels of $\mathrm{LH}$ and $E_{2}$ in serum of prepubertal rats, and it increased ovarian Cyp19a1 expression (Ma et al. 2006), the latter two in disagreement with more recent findings. Perhaps this difference is due to differences in the experimental approaches used (in vivo versus in vitro) as well as exposure routes and doses given. In cultured rat granulosa cells, MEHP (50 and $100 \mu \mathrm{M})$ decreased Cyp19a1 mRNA and protein (Lovekamp \& Davis 2001), induced the expression of 17 $\beta$-hydroxysteroid dehydrogenase IV (Hsd17b4), Ahr and Cyp1b1 and epoxide hydrolase (Ephx; Lovekamp-Swan et al. 2003). Thus, MEHP may alter $E_{2}$ levels by decreasing synthesis (decreased Cyp19a1) and by increasing its catabolism by Cyp1b1 and Hsd17b4, which are involved in $\mathrm{E}_{2}$ conversion to catechol estrogens and estrone respectively. Finally, although the majority of studies evaluating the effects of phthalates on ovarian function have focused on DEHP and MEHP, one study demonstrated that dioctylphthalate (DOP), diisodecylphthalate (DiDP), and diisononylphthalate (DiNP) possess endocrine-disrupting ability because they increase progesterone production by cultured porcine granulosa cells (Mlynarcíková et al. 2007). These findings indicate that phthalates, other than DEHP and MEHP, may alter ovarian processes and merit further investigation.

\section{Polyhalogenated arylhydrocarbons}

The subject of the molecular actions of polyhalogenated arylhydrocarbons, such as polychlorinated dibenzo-p-dioxins (PCDDs; dioxins) and polychlorinated biphenyls (PCBs) on female reproduction has been reviewed previously (Petroff et al. 2001, Hombach-Klonisch et al. 2005, Kotwica et al. 2006).
Therefore, this section focuses on recent findings on the ability of these chemicals to reduce the availability of ovarian hormones as a mechanism for ovarian endocrine disruption.

Dioxins are a class of environmental chemicals exemplified by $2,3,7,8$-tetrachlorodibenzo- $p$-dioxin (TCDD). The effects of TCDD on porcine steroidogenesis have been described by others and the subject has been reviewed previously (Gregoraszczuk 2002). Therefore, this section will focus on providing an updated and brief overview of the subject including data obtained using other species. A study in rats investigated whether maternal exposure to TCDD $(1 \mu \mathrm{g} / \mathrm{kg})$ damages gonadotropin-regulated steroidogenesis by fetal gonads and found that it decreased the expression of $\mathrm{LH}$ in the pituitaries, and decreased Star and Cyp17a1 mRNAs in the ovaries of the offspring (Takeda et al. 2009). Another study evaluated the effects of gestational and lactational exposure to TCDD $(0.04-1 \mu \mathrm{g} / \mathrm{kg})$ on ovarian steroidogenesis in rats, and observed that plasma progesterone levels were significantly increased in the absence of decreased steroidogenic enzyme expression when animals were given a dose of $1 \mu \mathrm{g} / \mathrm{kg}$ TCDD (Pesonen et al. 2006). In utero and lactational exposure of rats to TCDD $(0.04-1 \mu \mathrm{g} / \mathrm{kg})$ resulted in decreased $E_{2}$ levels in serum of dams and offspring, decreased levels of Star and increased levels of FSH when given at $1 \mu \mathrm{g} / \mathrm{kg}$. A lower dose of $0.2 \mu \mathrm{g} / \mathrm{kg}$ resulted in decreased Cyp19a 1 mRNA in that same study (Myllymäki et al. 2005b). In cultured immature rat granulosa cells, TCDD (10 pM) reduced $\mathrm{FSH}$-induced $\mathrm{LH}$ receptor mRNA expression (Minegishi et al. 2003). Furthermore, in whole rat ovary microarray studies, chronic TCDD exposure $(200 \mathrm{ng} / \mathrm{kg}$ per week) induced Cyp1b1, and downregulated Cyp17a1 and growth differentiation factor 9 (Gdf9), a paracrine factor involved in folliculogenesis (Valdez et al. 2009). Thus, evidence suggests that TCDD, such as other endocrine disruptors, decreases sex steroid hormone synthesis, but at the same time also increases catabolism of $E_{2}$, the major product of ovarian steroidogenesis.

PCBs are organic compounds widely used in dielectric fluids such as those in transformers, capacitors, and coolants. They exist in various forms termed $\mathrm{PCB}$ congeners. The idea of PCB exposure as a concern to humans is supported by studies reporting levels of various congeners in ovarian follicle fluid of women (total PCB $0.37 \mathrm{ng} / \mathrm{g}$ wet weight; De Felip et al. 2004) and in farm animals (0.45-3.05 depending on species; Kamarianos et al. 2003). Various studies have used different species and experimental models to evaluate the ability of PCBs to cause endocrine disruption in the ovary. In bovine luteal cells, PCBs 126, 77, and 153 (each given at $1-100 \mathrm{ng} / \mathrm{ml}$ ) did not alter basal luteal steroidogenesis, but were able to decrease $\mathrm{LH}$-stimulated secretion of progesterone in the luteal phase (Mlynarczuk \& Kotwica 2006). A 2 days exposure 
to PCB 153 (50 and $100 \mathrm{ng} / \mathrm{ml}$ ) decreased progesterone and testosterone secretion by porcine ovarian follicular cells. Interestingly, longer exposures increased progesterone secretion, accompanied by decreased testosterone and a tendency for decreased $E_{2}$ secretion (Gregoraszczuk \& Wójtowicz 2002). In porcine luteal cells, PCB $126(5-100 \mathrm{ng} / \mathrm{ml})$ was shown to decrease progesterone secretion, while the effect of PCB 153 was dependent on length of exposure. Specifically, between 48 and 72 h, PCB 153 decreased progesterone secretion, but after $72 \mathrm{~h}$, it induced a dose-dependent increase in progesterone secretion (Augustowska et al. 2001). A later study in the same in vitro model evaluated the effects of PCBs 153, 118, 180, and 138, and showed that congeners $153(8 \mu \mathrm{g} / \mathrm{ml}), 118(3 \mu \mathrm{g} / \mathrm{ml})$, and $180(3 \mu \mathrm{g} / \mathrm{ml})$ increased $E_{2}$ secretion, while congener $138(8 \mu \mathrm{g} / \mathrm{ml})$ increased testosterone secretion (Mlynarcíková et al. 2009). Although various studies have described the ability of PCBs to alter ovarian steroidogenesis, the molecular mechanisms underlying these alterations remain to be determined.

\section{Polycyclic aromatic hydrocarbons}

Polycyclic aromatic hydrocarbons (PAHs) are potent lipophilic pollutants that consist of fused aromatic rings. These chemicals can be formed during the incomplete combustion of carbon-containing substances such as wood, coal, and tobacco. This class of chemicals includes various members of which benzo[a]pyrene (BAP), dimethylbenz[a]anthracene (DMBA), phenanthrene, and chrysene are examples. Humans are exposed to PAHs mainly through tobacco smoking. Although PAHs are recognized as potent toxicants, not many studies have evaluated their ability to alter levels of ovarian steroids directly. However, several members of this family have been described as potent ovotoxicants (e.g. DMBA and BAP) that indirectly may alter levels of hormones by depleting follicles before they reach the steroid-producing antral stage. The topic of $\mathrm{PAH}$ induced depletion of preantral follicles has been briefly reviewed elsewhere (Miller et al. 2004). One study using isolated preantral follicles from rats showed that treatment with BAP $(\geq 1.5 \mathrm{ng} / \mathrm{ml})$ inhibited follicular growth, and decreased $E_{2}$ and anti-Müllerian hormone output (Neal et al. 2010). In rats, BAP (5 and $10 \mathrm{mg} / \mathrm{kg}$ ) has been shown to decrease levels of $E_{2}$ and decrease aromatase mRNA and protein (Xu et al. 2010). Furthermore, BAP, phenanthrene, and chrysene inhibited androstenedione and $E_{2}$ secretion by ovarian tissues of flounder treated with each chemical individually at $15 \mu \mathrm{M}$ (Monteiro et al. 2000, Rocha Monterio et al. 2000) and phenanthrenequinone (100-1000 nM), a metabolite of phenanthrene, reduced LH-stimulated progesterone in rat luteal cells (Nykamp et al. 2001). Despite the limited data currently available, the influence of PAHs on steroidogenesis is evident and, thus, it is reasonable to predict that studies aimed at understanding their mechanisms of action are forthcoming.

\section{Chemicals that alter hormone receptor binding and action}

\section{Estrogen receptors}

$\mathrm{E}_{2}$ plays critical roles in female reproduction. The biological functions of estrogens are mainly mediated by two estrogen receptors: ESR1 and ESR2. The two ESR subtypes have distinct tissue expression patterns, ligand specificities, and functions (Pelletier 2000). In the ovary, ESR1 is expressed primarily in theca and interstitial cells and its main function is to regulate steroidogenesis in theca cells (Britt \& Findlay 2002). In contrast, ESR2 is predominantly expressed in granulosa cells and its main roles are FSH-directed granulosa cell differentiation, follicle maturation and ovulation (Drummond \& Fuller 2010). Many EDCs interfere with female reproductive function by activating or antagonizing ESRs. Different EDCs show distinct effects in the ovary depending on their binding affinity to different ESRs.

Diethylstilbestrol (DES) is a non-steroidal synthetic estrogen that was prescribed from the 1940s to 1970s to pregnant women to prevent miscarriages. By the 1970s, numerous studies showing multi-generational effects of DES on reproductive, cardiovascular, and immune systems lead to a ban on the use of this drug during pregnancy (Goldberg \& Flacone 1999). DES mimics the natural estrogen, $E_{2}$, through conserved protein-ligand contact and binds to both ESR1 and ESR2 with higher affinity than that of $E_{2}$ (Kuiper et al. 1997, le Maire et al. 2010). Animal studies have shown that neonatal exposure to DES ( $3 \mu \mathrm{g})$ induces abnormalities in the mouse ovary, including delayed folliculogenesis and polyovular follicles (Kim et al. 2009b). Interestingly, further studies on ESR deficient mice ( $\alpha$ ERKO and $\beta E R K O$ ) have shown that DES $(3 \mu \mathrm{g})$ induces ovarian abnormalities through different ESRs. Specifically, DES inhibits follicle formation and development through ESR1 (Kim et al. 2009b), whereas it induces polyovular follicles through ESR2 (Kirigaya et al. 2009). In mice, in utero exposure to DES $(100 \mu \mathrm{g} / \mathrm{kg})$ was shown to change ovarian morphology and alter ex vivo ovarian steroidogenesis in the offspring of the dosed dams (Haney et al. 1984). Furthermore, in vitro studies have demonstrated that DES can disrupt steroidogenesis by rat ovarian follicles. For example, DES $(1 \mu \mathrm{M})$ was shown to decrease $E_{2}$ and testosterone secretion by ovarian follicles without affecting cAMP levels or aromatase activity (Myllymäki et al. 2005a). These observations highlight the fact that some EDCs not only alter the availability of endogenous hormones (i.e. synthesis and metabolism), but also interfere with hormone signaling via their specific receptors.

Phytoestrogens are plant compounds with estrogenic biological activity. They have a phenolic A ring, which is 
crucial for ESR binding. Since they have much higher binding affinity for ESR2 compared with ESR1, they are thought to signal predominantly via ESR2 (Drummond \& Fuller 2010). Genistein, for example, has a 20 -fold higher binding affinity for ESR2 compared with ESR1. Studies have shown that neonatal exposure to environmentally relevant doses of genistein $(3 \mu \mathrm{g})$ leads to abnormalities in female reproductive functions in rodents, including reduced fertility, polyovular follicle formation, altered estrous cycles, and delayed parturition (Cimafranca et al. 2010). The effects of genistein on the ovary are comparable to the ovarian phenotype of $\beta E R K O$ mice, suggesting that the action of genistein is predominantly mediated via ESR2 (Jefferson et al. 2002). Like DES, genistein has also been shown to alter steroidogenesis. Specifically, genistein (0.1$1 \mu \mathrm{M})$ decreased ex vivo production of cAMP and testosterone by increasing aromatase activity in rat ovarian follicles (Myllymäki et al. 2005a).

The pesticide MXC is another example of an EDC that affects ovarian function through ESR. Studies using transfected cell lines have demonstrated that the active metabolites of MXC are agonists of ESR1, but antagonists for both ESR2 and AR (Gaido et al. 2000). Other studies have shown that fetal and neonatal exposure to MXC $(20 \mu \mathrm{g} / \mathrm{kg}$ and $100 \mathrm{mg} / \mathrm{kg})$ alters methylation on the promoter region of ESR2 and therefore suppresses the expression of ESR2, causing ovarian dysfunction in the rat (Armenti et al. 2008, Zama \& Uzumcu 2009). Interestingly, antral follicles overexpressing ESR1 have been shown to be more sensitive to toxicity by MXC and its metabolites in both in vivo and in vitro experiments (Tomic et al. 2006, Paulose et al. 2011). Increased sensitivity to MXC and metabolites in this model has been proposed to be due to differential mRNA expression of other receptors such as ESR2, AR, progesterone receptor (PGR), and AHR, as well as that of the xenobiotic-metabolizing enzyme Cyp3a41a (Paulose et al. 2011).

Early studies with BPA showed that it has estrogenic properties and its binding affinity to ESRs is lower than $\mathrm{E}_{2}$ or DES (Zama \& Uzumcu 2009). In vitro, BPA acts as an agonist for both ESR1 and ESR2 on a tissue-specific basis (Kurosawa et al. 2002), although in vivo findings suggest that it can also antagonize ESR2 function (Susiarjo et al. 2007). Furthermore, receptor binding assays show that BPA has higher affinity for ESR2 than ESR1 (Matthews et al. 2001). Also, receptor binding assays and X-ray crystal structure analyses have demonstrated that BPA binds strongly to human estrogen-related receptor $\gamma$ (ESRRG/ ERRY; Takayanagi et al. 2006, Matsushima et al. 2008). Animal studies have shown that prenatal and neonatal exposure to low environmentally relevant doses of BPA (25 and $250 \mathrm{mg} / \mathrm{kg}$ ) cause numerous abnormalities in the ovary and uterus (Maffini et al. 2006). BPA causes defects in synapsis and recombination in the homologous chromosomes in the fetal ovary, which are similar to the meiotic defects in the oocytes of $\beta E R K O$ fetal gonads, suggesting that BPA disrupts early oogenesis in mouse ovary via an ESR2 signaling pathway (Hunt et al. 2003, Susiarjo et al. 2007).

\section{Aryl hydrocarbon receptor}

The AHR is a ligand-activated nuclear transcription factor, which acts as an intracellular mediator of xenobiotic signaling pathways. The AHR and its nuclear partner AHR nuclear translocator (ARNT) are present in various ovarian cell types (oocytes, granulosa cells, and theca cells) in rodents, primates, and humans (Hernandez-Ochoa et al. 2010). In general, xenobiotics bind to the AHR, triggering the nuclear translocation and formation AHR-ARNT heterodimers. The ligand-AHRARNT active complex binds to the xenobiotic-responsive element on the promoter region of AHR-regulated genes and therefore alters their transcription (Pocar et al. 2005). These genes include Cyp1a1 and Cyp1b1, as well as genes that regulate cell proliferation and differentiation (Okey et al. 1994, Dasmahapatra et al. 2002, Barnett et al. 2007). Gene-depletion studies in mice have suggested that the AHR controls folliculogenesis by inducing apoptosis, which leads to germ cell nest breakdown and formation of primordial follicles (Benedict et al. 2000). It also regulates ovarian follicular growth and steroidogenesis in antral follicles (Baba et al. 2005, Barnett et al. 2007, Hernandez-Ochoa et al. 2010).

Several studies indicate that the AHR mediates the ovarian toxicity of xenobiotics, such as TCDD and PCBs. TCDD has been shown to act through the AHR and affect follicle development, steroidogenesis, and ovulation. Animal studies have shown that chronic exposure to TCDD (50 and $200 \mathrm{ng} / \mathrm{kg}$ per week) induces premature reproductive senescence and decreases estradiol levels in female rats, without depletion of ovarian follicular reserves (Shi et al. 2007). In the porcine ovary, TCDD $(32 \mathrm{pg} / \mathrm{ml})$ induces the expression of AHR in granulosa, but not theca cells (Wojtowicz et al. 2005). In the rat ovary, TCDD $(32 \mu \mathrm{g} / \mathrm{kg})$ inhibits ovulation by suppressing the expression of prostaglandinendoperoxide synthase 2 (PTGS2, also known as cyclooxygenase-2 (COX-2)), a critical ovulation factor, via the AHR signaling pathway (Mizuyachi et al. 2002).

Finally, epidemiological studies of smokers have provided evidence suggesting that $\mathrm{PAHs}$ are ovotoxic in women (Weinberg et al. 1989). Animal studies also showed that PAHs destroy ovarian follicles via the AHR signaling pathway in rat and mice (Hombach-Klonisch et al. 2005). Maternal exposure to PAHs before pregnancy and/or during lactation (cumulative dose of $12 \mathrm{mg} / \mathrm{kg}$ ), compromises ovarian reserve of female offspring (Jurisicova et al. 2007). Further studies show that PAHs activate the AHR signaling pathway and induce the expression of pro-apoptotic genes, thus, accelerating germ cell depletion in mice (Pru et al. 2009). 


\section{Androgen receptor}

The AR is expressed in the ovaries of several species, including rodents, primates, and humans. The expression occurs in granulosa cells, oocytes and to a lesser extent in theca/interstitial cells (Pelletier 2000). Androgens and the AR have well known roles in male reproduction, but less is known about their roles in female reproduction. Studies of AR knockout mice have revealed that $A R$ function is essential for maintaining female fertility, by optimizing follicular growth, final follicle development, and ovulation (Walters et al. 2010). While toxicity studies related to androgens and the AR have focused on the effects of EDCs on male reproductive system, limited in vitro reporter gene assays have shown that the herbicide chlornitrofen exhibits antiandrogenic activity in Chinese hamster ovary cells (Kojima et al. 2003) while HPTE $(500 \mathrm{mg} / \mathrm{kg})$ was shown to be antiandrogenic in mouse ovarian and uterine tissues (Waters et al. 2001).

\section{Other hormone receptors}

In addition to the nuclear receptors discussed above, other hormone receptors, including PGR, FSHR, and $\mathrm{LHR}$, might play roles in EDC-induced ovarian toxicity. Several studies have shown that exposure to EDCs can alter the downstream signaling pathways of these hormone receptors by suppressing their expression. In vitro gene profiling studies have shown that exposure to HPTE $(5-10 \mu \mathrm{M})$, an active metabolite of MXC, affects the $\mathrm{FSH}$ signaling pathway and suppresses the expression of PGR and LHR in rat granulosa cells (Harvey et al. 2009). TCDD (10 pM) suppresses the expression and mRNA stability of $\mathrm{FSH}$-induced $\mathrm{LH}$ receptors in rat granulosa cells, suggesting that TCDD disrupts the signaling pathway that responds to $\mathrm{LH}$-induced ovulation (Minegishi et al. 2003). However, there is limited evidence showing that EDCs cause ovarian toxicity by directly affecting the binding and/or activation of these hormone receptors. Thus, more work needs to be done to define the mechanism of action of EDCs on receptors such as the PGR, FSHR, and LHR.

\section{Summary}

Many EDCs can interact with the female reproductive system and lead to endocrine disruption in the ovary. Although originally thought to exert their effects via binding transcription factor receptors, EDCs can alter endocrine function through a variety of mechanisms. In this review, we have discussed two major mechanisms by which EDCs may alter ovarian function. In the first mechanism discussed, chemicals may alter the expression and/or activity of enzymes required for synthesis and/or catabolism of ovarian sex steroids. Secondly, chemicals may alter the expression of hormone receptors and/or their ability to bind their endogenous ligands. There is no doubt that both mechanisms lead to altered ovarian function by altering endocrine signaling within the ovary and the rest of the reproductive organs. More studies, however, are needed to further understand the mechanisms of action of currently known EDCs, identify and characterize new EDCs, and expand toxicological research beyond commonly studied receptors and pathways.

\section{Declaration of interest}

The authors declare that there is no conflict of interest that could be perceived as prejudicing the impartiality of the research reported.

\section{Funding}

This work was supported by National Institute on Environmental Health Sciences (NIEHS) grants R01ES012893 (J A Flaws), R01ES019178 (J A Flaws), and a Billie A Field Fellowship in Reproductive Biology (Z R Craig).

\section{References}

Akgul Y, Derk R, Meighan T, Rao K \& Murono E 2008 The methoxychlor metabolite, HPTE, directly inhibits the catalytic activity of cholesterol side-chain cleavage (P450scc) in cultured rat ovarian cells. Reproductive Toxicology 25 67-75. (doi:10.1016/j.reprotox.2007.10.007)

Al-Saleh I, Coskun S, El-Doush I, Billedo G, Mashhour A, Jaroudi K, AlShahrani A, Al-Mayman H \& Mohamed G 2009 Outcome of in-vitro fertilization treatment and DDT levels in serum and follicular fluid. Medical Science Monitor 15 BR320-BR330.

Armenti A, Zama A, Passantino L \& Uzumcu M 2008 Developmental methoxychlor exposure affects multiple reproductive parameters and ovarian folliculogenesis and gene expression in adult rats. Toxicology and Applied Pharmacology 233 286-296. (doi:10.1016/j.taap. 2008.09.010)

Augustowska K, Wójtowicz A, Kajta M, Ropstad E \& Gregoraszczuk E 2001 Polichlorinated biphenyls (PCB126 and PCB153) action on proliferation and progesterone secretion by cultured in vitro porcine luteal cells. Experimental and Clinical Endocrinology \& Diabetes 109 416-418. (doi:10.1055/s-2001-18996)

Baba T, Mimura J, Nakamura N, Harada N, Yamamoto M, Morohashi K \& Fujii-Kuriyama $\mathbf{Y} 2005$ Intrinsic function of the aryl hydrocarbon (dioxin) receptor as a key factor in female reproduction. Molecular and Cellular Biology 25 10040-10051. (doi:10.1128/MCB.25.22.1004010051.2005)

Barnett K, Tomic D, Gupta R, Miller K, Meachum S, Paulose T \& Flaws J 2007 The aryl hydrocarbon receptor affects mouse ovarian follicle growth via mechanisms involving estradiol regulation and responsiveness. Biology of Reproduction 76 1062-1070. (doi:10.1095/biolreprod. 106.057687)

Basavarajappa MS, Craig ZR, Hernández-Ochoa I, Paulose T, Leslie TC \& Flaws JA 2011 Methoxychlor reduces estradiol levels by altering steroidogenesis and metabolism in mouse antral follicles in vitro. Toxicology and Applied Pharmacology 253 161-169. (doi:10.1016/j. taap.2011.04.007)

Benedict J, Lin T, Loeffler I, Peterson R \& Flaws J 2000 Physiological role of the aryl hydrocarbon receptor in mouse ovary development. Toxicological Sciences 56 382-388. (doi:10.1093/toxsci/56.2.382)

Britt K \& Findlay J 2002 Estrogen actions in the ovary revisited. Journal of Endocrinology 175 269-276. (doi:10.1677/joe.0.1750269) 
Brosens J 2004 Steroid receptor action. Best Practice \& Research. Clinical Obstetrics \& Gynaecology 18 265-283. (doi:10.1016/j.bpobgyn.2004. 01.006)

Carson RS, Findlay J, Burger H \& Trounson A 1979 Gonadotropin receptors of the ovine ovarian follicle during follicular growth and atresia. Biology of Reproduction 21 75-87. (doi:10.1095/biolreprod21.1.75)

Channing C \& Kammerman S 1974 Binding of gonadotropins to ovarian cells. Biology of Reproduction 10 179-198. (doi:10.1095/biolreprod10. 2.179)

Chedrese P \& Feyles F 2001 The diverse mechanism of action of dichlorodiphenyldichloroethylene (DDE) and methoxychlor in ovarian cells in vitro. Reproductive Toxicology 15 693-698. (doi:10.1016/ S0890-6238(01)00172-1)

Christenson L \& Strauss J III 2000 Steroidogenic acute regulatory protein (StAR) and the intramitochondrial translocation of cholesterol. Biochimica et Biophysica Acta 1529 175-187. (doi:10.1016/S13881981(00)00147-5)

Cimafranca M, Davila J, Ekman G, Andrews R, Neese S, Peretz J, Woodling K, Helferich W, Sarkar J, Flaws J et al. 2010 Acute and chronic effects of oral genistein administration in neonatal mice. Biology of Reproduction 83 114-121. (doi:10.1095/biolreprod.109.080549)

Craig Z, Leslie T, Hatfield K, Gupta R \& Flaws J 2010 Mono-hydroxy methoxychlor alters levels of key sex steroids and steroidogenic enzymes in cultured mouse antral follicles. Toxicology and Applied Pharmacology 249 107-113. (doi:10.1016/j.taap.2010.09.001)

Crellin N, Rodway M, Swan C, Gillio-Meina C \& Chedrese P 1999 Dichlorodiphenyldichloroethylene potentiates the effect of protein kinase A pathway activators on progesterone synthesis in cultured porcine granulosa cells. Biology of Reproduction 61 1099-1103. (doi:10.1095/biolreprod61.4.1099)

Crellin N, Kang H, Swan C \& Chedrese P 2001 Inhibition of basal and stimulated progesterone synthesis by dichlorodiphenyldichloroethylene and methoxychlor in a stable pig granulosa cell line. Reproduction 121 485-492. (doi:10.1530/rep.0.1210485)

Cummings A \& Laskey J 1993 Effect of methoxychlor on ovarian steroidogenesis: role in early pregnancy loss. Reproductive Toxicology 7 17-23. (doi:10.1016/0890-6238(93)90005-R)

Dasmahapatra A, Trewin A \& Hutz R 2002 Estrous cycle-regulated expression of CYP1B1 mRNA in the rat ovary. Comparative Biochemistry and Physiology. Part B, Biochemistry \& Molecular Biology 133 127-134 (doi:10.1016/S1096-4959(02)00119-7)

De Felip E, di Domenico A, Miniero R \& Silvestroni L 2004 Polychlorobiphenyls and other organochlorine compounds in human follicular fluid. Chemosphere 54 1445-1449. (doi:10.1016/j.chemosphere.2003. 10.040)

Diamanti-Kandarakis E, Bourguignon J-P, Giudice L, Hauser R, Prins G, Soto A, Zoeller R \& Gore A 2009 Endocrine-disrupting chemicals: an endocrine society scientific statement. Endocrine Reviews 30 293-342. (doi:10.1210/er.2009-0002)

Drummond A \& Fuller P 2010 The importance of ERbeta signalling in the ovary. Journal of Endocrinology 205 15-23. (doi:10.1677/JOE-090379)

Drummond A, Britt K, Dyson M, Jones M, Kerr J, O'Donnell L, Simpson E \& Findlay J 2002 Ovarian steroid receptors and their role in ovarian function. Molecular and Cellular Endocrinology 191 27-33. (doi:10. 1016/S0303-7207(02)00052-7

Falck B 1959 Site of production of oestrogen in rat ovary as studied in microtransplants. Acta Physiologica Scandinavica 47 1-101. (doi:10. 1111/j.1748-1716.1960.tb01823.x)

Foster W, Neal M \& Younglai E 2004 Endocrine disrupters and ovarian function. International Congress Series 1266 126-132. (doi:10.1016/j. ics.2004.01.066)

Furusawa N 2002 Transferring and distributing profiles of $p, p^{\prime}$-(DDT) in egg-forming tissues and eggs of laying hens following a single oral administration. Journal of Veterinary Medicine. A, Physiology, Pathology, Clinical Medicine 49 334-336. (doi:10.1046/j.1439-0442.2002.00432.x)

Gaido K, Maness S, McDonnell D, Dehal S, Kupfer D \& Safe S 2000 Interaction of methoxychlor and related compounds with estrogen receptor $\alpha$ and $\beta$, and androgen receptor: structure-activity studies. Molecular Pharmacology 58 852-858.
Gold B \& Brunk G 1982 Metabolism of 1,1,1-trichloro-2,2-bis( $p$ chlorophenyl)-ethane and 1,1-dichloro-2,2-bis( $p$-chlorophenyl)ethane in the mouse. Chemico-Biological Interactions 41 327-339. (doi:10. 1016/0009-2797(82)90109-0)

Goldberg J \& Flacone T 1999 Effect of diethylstilbestrol on reproductive function. Fertility and Sterility 72 1-7. (doi:10.1016/S0015-0282(99) 00153-3)

Grasselli F, Baratta L, Baioni L, Bussolati S, Ramoni R, Grolli S \& Basini G 2010 Bisphenol A disrupts granulosa cell function. Domestic Animal Endocrinology 39 34-39. (doi:10.1016/j.domaniend.2010.01. 004)

Gregoraszczuk E 2002 Dioxin exposure and porcine reproductive hormonal activity. Cadernos de Saúde Pública 18 453-462. (doi:10. 1590/S0102-311X2002000200010)

Gregoraszczuk E \& Wójtowicz A 2002 In vitro exposure of porcine ovarian follicular cells to PCB 153 alters steroid secretion by not their viability - preliminary study. Scientific World Journal 2 261-267. (doi:10.1100/tsw.2002.90)

Guillette L, Gross T, Gross D, Rooney A \& Percival H 1995 Gonadal steroidogenesis in vitro from juvenile alligators obtained from contaminated or control lakes. Environmental Health Perspectives 103 31-36.

Guillette L, Pickford D, Crain D, Rooney A \& Percival H 1996 Reduction in penis size and plasma testosterone concentrations in juvenile alligators living in a contaminated environment. General and Comparative Endocrinology 101 32-42. (doi:10.1006/gcen.1996.0005)

Gunnarsson D, Leffler P, Ekwurtzel E, Martinsson G, Liu K \& Selstam G 2008 Mono-(2-ethylhexyl) phthalate stimulates basal steroidogenesis by a cAMP-independent mechanism in mouse gonadal cells of both sexes. Reproduction 135 693-703. (doi:10.1530/REP-07-0460)

Gupta RK, Singh JM, Leslie TC, Meachum S, Flaws JA \& Yao HH 2010 Di-(2-ethylhexyl) phthalate and mono-(2-ethylhexyl) phthalate inhibit growth and reduce estradiol levels of antral follicles in vitro. Toxicology and Applied Pharmacology 242 224-230. (doi:10.1016/j.taap.2009.10. 011)

Haney A, Newbold R \& McLachlan J 1984 Prenatal diethylstilbestrol exposure in the mouse: effects on ovarian histology and steroidogenesis in vitro. Biology of Reproduction 30 471-478. (doi:10.1095/biolreprod30.2.471)

Hanukoglu I 1992 Steroidogenic enzymes: structure, function, and role in regulation of steroid hormone biosynthesis. Journal of Steroid Biochemistry and Molecular Biology 43 779-804. (doi:10.1016/09600760(92)90307-5)

Harvey C, Esmail M, Wang Q, Brooks A, Zachow R \& Uzumcu M 2009 Effect of the methoxychlor metabolite HPTE on the rat ovarian granulosa cell transcriptome in vitro. Toxicological Sciences 110 95-106. (doi:10. 1093/toxsci/kfp089)

Hayes C, Spink D, Spink B, Cao J \& Walker N 1996 17ß-Estradiol hydroxylation catalyzed by human cytochrome P450 1B1. PNAS 93 9776-9781. (doi:10.1073/pnas.93.18.9776)

Hengstler J, Foth H, Gebel T, Kramer P-J, Lilienblum W, Schweinfurth $\mathbf{H}$, Völkel W, Wollin K-M \& Gundert-Remy U 2011 Critical evaluation of key evidence on the human health hazards of exposure to bisphenol A. Critical Reviews in Toxicology 41 263-291. (doi:10.3109/10408444. 2011.558487)

Hernandez-Ochoa I, Barnett-Ringgold K, Dehlinger S, Gupta R, Leslie T, Roby K \& Flaws J 2010 The ability of the aryl hydrocarbon receptor to regulate ovarian follicle growth and estradiol biosynthesis in mice depends on stage of sexual maturity. Biology of Reproduction 83 698-706. (doi:10.1095/biolreprod.110.087015)

Hombach-Klonisch S, Pocar P, Kietz S \& Klonisch T 2005 Molecular actions of polyhalogenated arylhydrocarbons (PAHs) in female reproduction. Current Medicinal Chemistry 12 599-616.

Hunt PA, Koehler KE, Susiarjo M, Hodges CA, Ilagan A, Voigt RC Thomas S, Thomas BF \& Hassold TJ 2003 Bisphenol A exposure causes meiotic aneuploidy in the female mouse. Current Biology 13 546-553. (doi:10.1016/S0960-9822(03)00189-1)

Imai H \& Coulston F 1968 Ultrastructural studies of absorption of methoxychlor in the jejunal mucosa of the rat. Experimental and Molecular Pathology 8 135-158. (doi:10.1016/0014-4800(68) 90012-9) 
Jarrell J, Villeneuve D, Franklin C, Bartlett S, Wrixon W, Kohut J \& Zouves C 1993 Contamination of human ovarian follicular fluid and serum by chlorinated organic compounds in three Canadian cities. CMAJ: Canadian Medical Association Journal 148 1321-1327.

Jefferson W, Couse J, Padilla-Banks E, Woodling K, Kissling G \& Newbold R 2002 Neonatal exposure to genistein induces estrogen receptor (ER)alpha expression and multioocyte follicles in the maturing mouse ovary. Biology of Reproduction 67 1285-1296. (doi:10.1095/ biolreprod67.4.1285)

Jefferson W, Doerge D, Padilla-Banks E, Woodling K, Kissling G \& Newbold R 2009 Oral exposure to genistin, the glycosylated form of genistein, during neonatal life adversely affects the female reproductive system. Environmental Health Perspectives 117 1883-1889. (doi:10. 1289/ehp.0900923)

Jurisicova A, Taniuchi A, Li H, Shang Y, Antenos M, Detmar J, Xu J, Matikainen T, Benito Hernandez A, Nunez G et al. 2007 Maternal exposure to polycyclic aromatic hydrocarbons diminishes murine ovarian reserve via induction of Harakiri. Journal of Clinical Investigation 117 3971-3978. (doi:10.1172/JCl28493)

Kamarianos A, Karamanlis X, Goulas P, Theodosiadou E \& Smokovitis A 2003 The presence of environmental pollutants in the follicular fluid of farm animals (cattle, sheep, goats and pigs). Reproductive Toxicology 17 185-190. (doi:10.1016/S0890-6238(02)00118-1)

Kapoor IP, Metcalf RL, Nystrom RF \& Sangha GK 1970 Comparative metabolism of methoxychlor, methiochlor, and DDT in mouse, insects, and in a model ecosystem. Journal of Agricultural and Food Chemistry 18 1145-1152. (doi:10.1021/jf60172a017)

Kim H, Hayashi S, Chambon P, Watanabe H, Iguchi T \& Sato T 2009a Effects of diethylstilbestrol on ovarian follicle development in neonatal mice. Reproductive Toxicology 27 55-62. (doi:10.1016/j.reprotox.2008. 10.005)

Kim H, Nakajima T, Hayashi S, Chambon P, Watanabe H, Iguchi T \& Sato T $2009 \mathrm{~b}$ Effects of diethylstilbestrol on programmed oocyte death and induction of polyovular follicles in neonatal mouse ovaries. Biology of Reproduction 81 1002-1009. (doi:10.1095/biolreprod.108.070599)

Kirigaya A, Kim H, Hayashi S, Chambon P, Watanabe H, Lguchi T \& Sato T 2009 Involvement of estrogen receptor beta in the induction of polyovular follicles in mouse ovaries exposed neonatally to diethylstilbestrol. Zoological Science 26 704-712. (doi:10.2108/zsj.26.704)

Kojima H, lida M, Katsura E, Kanetoshi A, Hori Y \& Kobayashi K 2003 Effects of a diphenyl ether-type herbicide, chlornitrofen, and its amino derivative on androgen and estrogen receptor activities. Environmental Health Perspectives 111 497-502. (doi:10.1289/ehp.5724)

Kotwica J, Wróbel M \& Mlynarczuk J 2006 The influence of polychlorinated biphenyls (PCBs) and phytoestrogens in vitro on functioning of reproductive tract in cow. Reproductive Biology 6 189-194.

Kuiper G, Carlsson B, Grandien K, Enmark E, Haggblad J, Nilsson S \& Gustafsson J 1997 Comparison of the ligand binding specificity and transcript tissue distribution of estrogen receptors alpha and beta. Endocrinology 138 863-870. (doi:10.1210/en.138.3.863)

Kurosawa $T$, Hiroi $H$, Tsutsumi $O$, Ishikawa $T$, Osuga $Y$, Fugiwara $T$, Inoue S, Muramatsu M, Momoeda M \& Taketani Y 2002 The activity of bisphenol A depends on both the estrogen receptor subtype and the cell type. Endocrine Journal 49 465-471. (doi:10.1507/endocrj.49.465)

Kwintkiewicz J, Nishi Y, Yanase T \& Giudice L 2010 Peroxisome proliferator-activated receptor- $\gamma$ mediates bisphenol A inhibition of FSH-stimulated IGF-1, aromatase, and estradiol in human granulosa cells. Environmental Health Perspectives 118 400-406. (doi:10.1289/ ehp.0901161)

Lenie S \& Smitz J 2009 Steroidogenesis-disrupting compounds can be effectively studied for major fertility-related endpoints using in vitro cultured mouse follicles. Toxicology Letters 185 143-152. (doi:10.1016/ j.toxlet.2008.12.015)

Li H-C \& Kupfer D 1998 Mechanism of induction of rat hepatic CYP2B and $3 \mathrm{~A}$ by the pesticide methoxychlor. Journal of Biochemical and Molecular Toxicology 12 315-323. (doi:10.1002/(SICI)1099-0461(1998)12:6< 315::AID-JBT1 > 3.0.CO;2-6)

Lovekamp T \& Davis B 2001 Mono-(2-ethylhexyl) phthalate suppresses aromatase transcript levels and estradiol production in cultured rat granulosa cells. Toxicology and Applied Pharmacology 172 217-224. (doi:10.1006/taap.2001.9156)
Lovekamp-Swan T \& Davis BJ 2003 Mechanisms of phthalate ester toxicity in the female reproductive system. Environmental Health Perspectives 111 139-145. (doi:10.1289/ehp.5658)

Lovekamp-Swan T, Jetten A \& Davis B 2003 Dual activation of PPARalpha and PPARgamma by mono-(2-ethylhexyl)phthalate in rat ovarian granulosa cells. Molecular and Cellular Endocrinology 201 133-141. (doi:10.1016/S0303-7207(02)00423-9)

Ma M, Kondo T, Ban S, Umemura T, Kurahashi N, Takeda M \& Kishi R 2006 Exposure of prepubertal female rats to inhaled di(2-ethylhexyl)phthalate affects the onset of puberty and postpubertal reproductive functions. Toxicological Sciences 93 164-171. (doi:10.1093/toxsci/kfl036)

Maffini M, Rubin B, Sonnenschein C \& Soto A 2006 Endocrine disruptors and reproductive health: the case of bisphenol-A. Molecular and Cellular Endocrinology 254-255 179-186. (doi:10.1016/j.mce.2006.04.033)

Magoffin D \& Erickson G 1982 Primary culture of differentiating ovarian androgen-producing cells in defined medium. Journal of Biological Chemistry 25 4507-4513.

le Maire A, Bourguet W \& Balaguer P 2010 A structural view of nuclear hormone receptor: endocrine disruptor interactions. Cellular and Molecular Life Sciences 67 1219-1237. (doi:10.1007/s00018-0090249-2)

Matsushima A, Teramoto T, Okada H, Liu X, Tokunaga T, Kakuta Y \& Shimohigashi Y 2008 ERR $\gamma$ tethers strongly bisphenol A and 4- $\alpha-$ cumylphenol in an induced-fit manner. Biochemical and Biophysical Research Communications 373 408-413. (doi:10.1016/j.bbrc.2008.06. 050)

Matthews J, Twomey K \& Zacharewski T 2001 In vitro and in vivo interactions of bisphenol A and its metabolite, bisphenol A glucuronide, with estrogen receptors alpha and beta. Chemical Research in Toxicology 14 149-157. (doi:10.1021/tx0001833)

Meeker J, Missmer S, Altshul L, Vitonis A, Ryan L, Cramer D \& Hauser R 2009 Serum and follicular fluid organochlorine concentrations among women undergoing assisted reproduction technologies. Environmental Health 8 32. (doi:10.1186/1476-069X-8-32)

Miller W 1988 Molecular biology of steroid hormone synthesis. Endocrine Reviews 9 295-318. (doi:10.1210/edrv-9-3-295)

Miller K, Borgeest C, Greenfeld C, Tomic D \& Flaws J 2004 In utero effects of chemicals on reproductive tissues in females. Toxicology and Applied Pharmacology 198 111-131. (doi:10.1016/j.taap.2003. 07.016)

Minegishi T, Hirakawa T, Abe H, Kishi H \& Miyamoto K 2003 Effect of IGF-1 and 2,3,7,8-tetrachlorodibenzo- $p$-dioxin (TCDD) on the expression of $\mathrm{LH}$ receptors during cell differentiation in cultured granulosa cells. Molecular and Cellular Endocrinology 202 123-131. (doi:10.1016/ S0303-7207(03)00073-X)

Mizuyachi K, Son D, Rozman K \& Terranova P 2002 Alteration in ovarian gene expression in response to 2,3,7,8-tetrachlorodibenzo- $p$-dioxin: reduction of cyclooxygenase-2 in the blockage of ovulation. Reproductive Toxicology 16 299-307. (doi:10.1016/S0890-6238(02)00024-2)

Mlynarcíková A, Kolena J, Ficková M \& Scsuková S 2005 Alterations in steroid hormone production by porcine ovarian granulosa cells caused by bisphenol A and bisphenol A dimethacrylate. Molecular and Cellular Endocrinology 244 57-62. (doi:10.1016/j.mce.2005.02.009)

Mlynarcíková A, Ficková M \& Scsuková S 2007 The effects of selected phenol and phthalate derivatives on steroid hormone production by cultured porcine granulosa cells. Alternatives to Laboratory Animals 35 71-77.

Mlynarcíková A, Nagyová E, Ficková M \& Scsuková S 2009 Effects of selected endocrine disruptors on meiotic maturation, cumulus expansion, synthesis of hyaluronan and progesterone by porcine oocytecumulus complexes. Toxicology In Vitro 23 371-377. (doi:10.1016/j.tiv. 2008.12.017)

Mlynarczuk J \& Kotwica J 2006 Influence of polychlorinated biphenyls on LH-stimulated secretion of progesterone and oxytocin from bovine luteal cells. Polish Journal of Veterinary Sciences 9 101-108.

Monteiro P, Reis-Henriques M \& Coimbra J 2000 Plasma steroid levels in female flounder (Platichthys flesus) after chronic dietary exposure to single polycyclic aromatic hydrocarbons. Marine Environmental Research 49 453-467. (doi:10.1016/S0141-1136(99)00085-9)

Myllymäki S, Haavisto T, Vainio M, Toppari J \& Paranko J 2005a In vitro effects of diethylstilbestrol, genistein, 4-tert-butylphenol, and 
4-tert-octylphenol on steroidogenic activity of isolated immature rat ovarian follicles. Toxicology and Applied Pharmacology 204 69-80. (doi:10.1016/j.taap.2004.08.009)

Myllymäki S, Haavisto T, Brokken L, Viluksela M, Toppari J \& Paranko J $2005 \mathrm{~b}$ In utero and lactational exposure to TCDD; steroidogenic outcomes differ in male and female rat pups. Toxicological Sciences $\mathbf{8 8}$ 534-544. (doi:10.1093/toxsci/kfi308)

Neal M, Mulligan Tuttle A, Casper R, Lagunov A \& Foster W 2010 Aryl hydrocarbon receptor antagonists attenuate the deleterious effects of benzo[a]pyrene on isolated rat follicle development. Reproductive BioMedicine Online 21 100-108. (doi:10.1016/j.rbmo.2010.03.025)

Nims R, Lubet R, Fox S, Jones C, Thomas P, Reddy A \& Kocarek T 1998 Comparative pharmacodynamics of CYP2B induction by DDT, DDE, and DDD in male rat liver and cultured rat hepatocytes. Journal of Toxicology and Environmental Health. Part A 53 455-477.

Nykamp J, Bols N \& Carlson J 2001 Phenanthrenequinone disrupts progesterone production in rat luteal cells. Reproductive Toxicology $\mathbf{1 5}$ 393-398. (doi:10.1016/S0890-6238(01)00140-X)

Okey A, Riddick D \& Harper P 1994 The Ah receptor: mediator of the toxicity of 2,3,7,8-tetrachlorodibenzo-p-diozin (TCDD) and related compounds. Toxicology Letters 70 1-22. (doi:10.1016/0378-4274(94) 90139-2)

Oktem O \& Urman B 2010 Understanding follicle growth in vivo. Human Reproduction 25 2944-2954. (doi:10.1093/humrep/deq275)

Paulose T, Hernández-Ochoa I, Basavarajappa M, Peretz J \& Flaws J 2011 Increased sensitivity of estrogen receptor alpha overexpressing antral follicles to methoxychlor and its metabolites. Toxicological Sciences $\mathbf{1 2 0}$ 447-459. (doi:10.1093/toxsci/kfr011)

Pelletier G 2000 Localization of androgen and estrogen receptors in rat and primate tissues. Histology and Histopathology 15 1261-1270.

Penning T 1997 Molecular endocrinology of hydroxysteroid dehydrogenases. Endocrine Reviews 18 281-305. (doi:10.1210/er.18.3.281)

Peretz J, Gupta R, Singh J, Hernández-Ochoa I \& Flaws J 2011 Bisphenol A impairs follicle growth, inhibits steroidogenesis, and downregulates rate-limiting enzymes in the estradiol biosynthesis pathway. Toxicological Sciences 119 209-217. (doi:10.1093/toxsci/ kfq319)

Pesonen S, Haavisto T, Viluksela M, Toppari J \& Paranko J 2006 Effects of in utero and lactational exposure to 2,3,7,8-tetrachlorodibenzo- $p$-dioxin (TCDD) on rat follicular steroidogenesis. Reproductive Toxicology 22 521-528. (doi:10.1016/j.reprotox.2006.03.007)

Petroff B, Roby K, Gao X, Son D, Williams S, Johnson D, Rozman K \& Terranova P 2001 A review of mechanisms controlling ovulation with implications for the anovulatory effects of polychlorinated dibenzop-dioxins in rodents. Toxicology 158 91-107. (doi:10.1016/S0300-483X (00)00367-X)

Pickford D \& Morris I 1999 Effects of endocrine-disrupting contaminants on amphibian oogenesis: methoxychlor inhibits progesterone-induced maturation of Xenopus laevis oocytes in vitro. Environmental Health Perspectives 107 285-292. (doi:10.1289/ehp.99107285)

Pickford D \& Morris I 2003 Inhibition of gonadotropin-induced oviposition and ovarian steroidogenesis in the African clawed frog (Xenopus laevis) by the pesticide methoxychlor. Aquatic Toxicology 62 179-194. (doi:10.1016/S0166-445X(02)00082-6)

Pocar P, Fischer B, Klonisch T \& Hombach-Klonisch S 2005 Molecular interactions of the aryl hydrocarbon receptor and its biological and toxicological relevance for reproduction. Reproduction 129 379-389. (doi:10.1530/rep.1.00294)

Pru J, Kaneko-Tarui T, Jurisicova A, Kashiwagi A, Selesniemi K \& Tilly J 2009 Induction of proapoptotic gene expression and recruitment of p53 herald ovarian follicle loss caused by polycyclic aromatic hydrocarbons. Reproductive Sciences 16 347-356. (doi:10.1177/ 1933719108327596)

Reinsberg J, Wegener-Toper P, van der Ven K, van der Ven $\mathbf{H}$ \& Klingmueller D 2009 Effect of mono-(2-ethylhexyl) phthalate on steroid production of human granulosa cells. Toxicology and Applied Pharmacology 239 116-123. (doi:10.1016/j.taap.2009.05.022)

Richards J 1980 Maturation of ovarian follicles: actions and interactions of pituitary and ovarian hormones on follicular cell differentiation. Physiological Reviews 60 51-89.
Rocha Monterio P, Reis-Henriques M \& Coimbra J 2000 Polycyclic aromatic hydrocarbons inhibit in vitro ovarian steroidogenesis in the flounder (Platichthys flesus L.). Aquatic Toxicology 48 549-559. (doi:10. 1016/S0166-445X(99)00055-7)

Shi Z, Valdez K, Ting A, Franczak A, Gum S \& Petroff B 2007 Ovarian endocrine disruption underlies premature reproductive senescence following environmentally relevant chronic exposure to the aryl hydrocarbon receptor agonist 2,3,7,8-tetrachlorodibenzo-p-dioxin. Biology of Reproduction 76 198-202. (doi:10.1095/biolreprod.106. 053991)

Stocco D 2001 StAR protein and the regulation of steroid hormone biosynthesis. Annual Review of Physiology 63 193-213. (doi:10.1146/ annurev.physiol.63.1.193)

Stoker C, Beldoménico P, Bosquiazzo V, Zayas M, Rey F, Rodríguez H, Muñoz-de-Toro M \& Luque E 2008 Developmental exposure to endocrine disruptor chemicals alters follicular dynamics and steroid levels in Caiman latirostris. General and Comparative Endocrinology 156 603-612. (doi:10.1016/j.ygcen.2008.02.011)

Strauss J III, Kallen C, Christenson L, Watari H, Devoto L, Arakane F \& Kiriakidou M 1999 The steroidogenic acute regulatory protein (StAR): a window into the complexities of intracellular cholesterol trafficking. Recent Progress in Hormone Research 54394.

Susiarjo M, Hassold T, Freeman E \& Hunt P 2007 Bisphenol A exposure in utero disrupts early oogenesis in the mouse. PLoS Genetics 3 e5. (doi:10. 1371/journal.pgen.0030005)

Svechnikova I, Svechnikov K \& Söder O 2007 The influence of di(2-ethylhexyl) phthalate on steroidogenesis by the ovarian granulosa cells of immature female rats. Journal of Endocrinology 194 603-609. (doi:10. 1677/JOE-07-0238)

Takayanagi S, Tokunaga T, Liu X, Okada H, Matsushima A \& Shimohigashi Y 2006 Endocrine disruptor bisphenol A strongly binds to human estrogenrelated receptor $\gamma(E R R \gamma)$ with high constitutive activity. Toxicology Letters 167 95-105. (doi:10.1016/j.toxlet.2006.08.012)

Takeda T, Matsumoto Y, Koga T, Mutoh J, Nishimura Y, Shimazoe T, Ishii Y, Ishida T \& Yamada H 2009 Maternal exposure to dioxin disrupts gonadotropin production in fetal rats and imprints defects in sexual behavior. Journal of Pharmacology and Experimental Therapeutics 329 1091-1099. (doi:10.1124/jpet.109.151282)

Tiemann U 2008 In vivo and in vitro effects of the organochlorine pesticides DDT, TCPM, methoxychlor, and lindane on the female reproductive tract of mammals: a review. Reproductive Toxicology 25 316-326. (doi:10. 1016/j.reprotox.2008.03.002)

Tomic D, Frech MS, Babus JK, Gupta RK, Furth PA, Koos RD \& Flaws JA 2006 Methoxychlor induces atresia of antral follicles in ERalphaoverexpressing mice. Toxicological Sciences 93 196-204. (doi:10. 1093/toxsci/kfl040)

Tsuchiya Y, Nakajima M \& Yokoi T 2005 Cytochrome P450-mediated metabolism of estrogens and its regulation in human. Cancer Letters 227 115-124. (doi:10.1016/j.canlet.2004.10.007)

Valdez K, Shi Z, Ting A \& Petroff B 2009 Effect of chronic exposure to the aryl hydrocarbon receptor agonist 2,3,7,8-tetrachlorodibenzo-p-dioxin in female rats on ovarian gene expression. Reproductive Toxicology $\mathbf{2 8}$ 32-37. (doi:10.1016/j.reprotox.2009.03.004)

Walters K, Simanainen U \& Handelsman D 2010 Molecular insights into androgen actions in male and female reproductive function from androgen receptor knockout models. Human Reproduction Update $\mathbf{1 6}$ 543-558. (doi:10.1093/humupd/dmq003)

Wang C, Hsueh A \& Erickson G 1982 The role of cyclic AMP in the induction of estrogen and progestin synthesis in cultured granulosa cells. Molecular and Cellular Endocrinology 25 73-83. (doi:10.1016/03037207(82)90170-8)

Wang J, Liu X, Wang H, Wu T, Hu X, Qin F \& Wang Z 2010 Expression of two cytochrome $\mathrm{P} 450$ aromatase genes is regulated by endocrine disrupting chemicals in rare minnow Gobiocypris rarus juveniles. Comparative Biochemistry and Physiology. Toxicology \& Pharmacology 152 313-320. (doi:10.1016/j.cbpc.2010.05.007)

Waters KM, Safe S \& Gaido KW 2001 Differential gene expression in response to methoxychlor and estradiol through $E R \alpha$, ER $\beta$, and $A R$ in reproductive tissues of female mice. Toxicological Sciences 63 47-56. (doi:10.1093/toxsci/63.1.47) 
Weinberg C, Wilcox A \& Baird D 1989 Reduced fecundability in women with prenatal exposure to cigarette smoking. American Journal of Epidemiology 129 1072-1078.

Wojtowicz A, Tomanek M, Augustowska K \& Gregoraszczuk E 2005 Aromatic hydrocarbon receptor (AhR) in the porcine theca and granulosa cells: effect of TCDD, PCB126 and PCB 153 on the expression of AhR. Endocrine Regulations 39 109-118.

Wójtowicz A, Kajta M \& Gregoraszczuk E 2007 DDT- and DDE-induced disruption of ovarian steroidogenesis in prepubertal porcine ovarian follicles: a possible interaction with the main steroidogenic enzymes and estrogen receptor $\beta$. Journal of Physiology and Pharmacology 58 873-885.

Wu Y, Foster W \& Younglai E 2006 Rapid effects of pesticides on human granulosa-lutein cells. Reproduction 131 299-310. (doi:10.1530/rep.1. 00922)

Xu C, Chen J-A, Qiu Z, Zhao Q, Luo J, Yang L, Zeng H, Huang Y, Zhang L, Cao J et al. 2010 Ovotoxicity and PPAR-mediated aromatase downregulation in female Sprague-Dawley rats following combined oral exposure to benzo[a]pyrene and di-(2-ethylhexyl) pthalate. Toxicology Letters 199 323-332. (doi:10.1016/j.toxlet.2010.09.015)

Younglai E, Holloway A, Lim G \& Foster W 2004a Synergistic effects between FSH and 1,1-dichloro-2,2-bis( $P$-chlorophenyl)ethylene $\left(P, P^{\prime}\right.$-DDE) on human granulosa cell aromatase activity. Human Reproduction 19 1089-1093. (doi:10.1093/humrep/deh252)
Younglai E, Kwan T, Kwan C-Y, Lobb D \& Foster W $2004 b$ Dichlorodiphenylchloroethylene elevates cytosolic calcium concentrations and oscillations in primary cultures of human granulosa-lutein cells. Biology of Reproduction 70 1693-1700. (doi:10.1095/biolreprod. 103.026187)

Zachow R \& Uzumcu M 2006 The methoxychlor metabolite, 2,2-bis( $p$ hydroxyphenyl)-1,1,1-trichloroethane, inhibits steroidogenesis in rat ovarian granulosa cells in vitro. Reproductive Toxicology 22 659-665. (doi:10.1016/j.reprotox.2006.04.018)

Zama A \& Uzumcu M 2009 Fetal and neonatal exposure to the endocrine disruptor methoxychlor causes epigenetic alterations in adult ovarian genes. Endocrinology 150 4681-4691. (doi:10.1210/en. 2009-0499)

Zhou W, Liu J, Liao L, Han S \& Liu J 2008 Effect of bisphenol A on steroid hormone production in rat ovarian theca-interstitial and granulosa cells. Molecular and Cellular Endocrinology 283 12-18. (doi:10.1016/j.mce. 2007.10.010)

Received 25 April 2011

First decision 27 June 2011

Accepted 23 August 2011 